Check for updates

Cite this: RSC Adv., 2018, 8, 21030

\title{
Recyclable $\mathrm{Pd} / \mathrm{CuFe}_{2} \mathrm{O}_{4}$ nanowires: a highly active catalyst for $\mathrm{C}-\mathrm{C}$ couplings and synthesis of benzofuran derivatives $\uparrow$
}

\author{
Bhairi Lakshminarayana, Jhonti Chakraborty, G. Satyanarayana (D) * \\ and Ch. Subrahmanyam (D)*
}

Received 30th April 2018

Accepted 1st June 2018

DOI: $10.1039 / \mathrm{c} 8 \mathrm{ra} 03697 \mathrm{~g}$

rsc.li/rsc-advances

\begin{abstract}
$\mathrm{Pd} / \mathrm{CuFe}_{2} \mathrm{O}_{4}$ nanowire-catalyzed cross coupling transformations are described. Notably, these reactions showed excellent functional group tolerance. Further, the protocol is applied to a one-pot synthesis of benzofurans via a Sonogashira coupling and intramolecular etherification sequence. The catalyst was reused and found to maintain its activity and stability.
\end{abstract}

\section{Introduction}

The ability to form various $\mathrm{C}-\mathrm{C}$ bonds under transition metal catalysis is important in organic synthesis. Particularly, one-pot construction of heterocyclic core structures of biological relevance is indispensable. ${ }^{1}$ In this context, Pd is one of the most widely used transition metals for a variety of coupling transformations. When compared with homogeneous counterparts, heterogeneous catalysts enable the formation of less contaminated products and promote green chemistry ${ }^{1-3}$ In the recent past, heterogeneous catalysis, for the formation of $\mathrm{C}-\mathrm{C}, \mathrm{C}-\mathrm{O}$, $\mathrm{C}-\mathrm{N}$ and $\mathrm{C}-\mathrm{S}$ bonds, became the central part of synthetic chemistry. Amongst them all, carbon-carbon (C-C) bond forming reactions for the preparation of carbon scaffolds are of high importance from the organic synthetic viewpoint.

Supported nanocatalysts have become an integral part of heterogeneous catalysis for various organic transformations and industrial applications. ${ }^{4-7}$ Especially, metal oxide supported heterogeneous nanocatalysts are preferred because of their activity, better selectivity, and high stability over conventional metal based catalyst frameworks. ${ }^{8}$ Unsupported nanocatalysts face problems due to issues related recovery and recyclability from the reaction mixture. ${ }^{9}$ This problem can be resolved by immobilizing the active species on a support having high surface area materials such as nano-metal oxides, ${ }^{\mathbf{1 0}}$ carbon nano-materials, ${ }^{11,12}$ polymers ${ }^{13}$ etc. Among all the supporters, nano-metal oxide supported nanocatalysts are easily separable from the reaction mixture. ${ }^{14,15}$ Especially, the substitution of the copper ion into the ferrite lattice constitutes a well-developed

Department of Chemistry, Indian Institute of Technology Hyderabad, Kandi, Sangareddy, 502285, Telangana, India.E-mail: gvsatya@iith.ac.in; csubbu@iith.ac. in; Tel: +91(40) 23016054

$\dagger$ Electronic supplementary information (ESI) available: Details of catalyst synthesis, characterization and experimental studies. ${ }^{1} \mathrm{H},{ }^{13} \mathrm{C}-\mathrm{NMR}$ spectra of all isolated products. See DOI: 10.1039/c8ra03697g category of the mixed metal ferrites for catalysis in organic reactions. ${ }^{16,17}$ In this context, we designed $\mathrm{CuFe}_{2} \mathrm{O}_{4}$ support for organic transformation reactions (C-C couplings).

The biaryls and diarylacetylenes are useful scaffolds that constitute pharmaceuticals, agrochemicals and biologically active compounds. ${ }^{17,18}$ The Suzuki-Miyaura cross-coupling reactions of aryl halides with aryl boronic acids and Sonogashira coupling reactions of aryl halides with arylacetylenes are considered to be important carbon-carbon bond forming strategies, for constructing biaryls and internal acetylenes, respectively. ${ }^{19-21}$ However, most of these reactions made use of toxic ligands in conjunction with Pd-salts or Pd nanoparticles and $\mathrm{Pd} / \mathrm{Cu}$ nanoparticles. ${ }^{22}$ Benzofuran derivatives are an important class of heterocyclic compounds, due to their miscellaneous biological profile, such as analgesia, antitumor, antimicrobial, kinase inhibitor and antihyperglycemic activities. ${ }^{23-28}$ Recently, the research group of Mariusz Jan Bosiak showed the utility of benzofurans in photovoltaic and optoelectronic properties, wherein benzofurans absorb and emit the light. ${ }^{29-32}$ While, one-pot synthesis of benzofurans, under homogeneous catalysis, is well established. Recently, the synthetic community turned their interest to develop new methods for the synthesis of benzofurans by means of heterogeneous catalytic conversion. ${ }^{33-39}$ Very recently, there have been various reports described that the catalytic activity of Pd nanoparticles can be retained, the stability of the Pd nanoparticles also enhanced to some extent by using magnetic nanomaterials as a supporter for immobilization of Pd nanoparticles. ${ }^{40-46}$ Recently, we have developed $\mathrm{Pd} / \mathrm{CuFe}_{2} \mathrm{O}_{4}$ nanowires and showed its synthetic utility toward Heck couplings. ${ }^{47}$ Herein, we present the applicability of catalyst for various $\mathrm{C}-\mathrm{C}$ bond forming reactions (Suzuki, Sonogashira). Further, this catalyst applied for the one-pot synthesis of benzofurans via intermolecular Sonogashira followed by intramolecular cyclization. Initially, a comparative study of as prepared catalyst with other recently reported Pd supported catalysts for Suzuki coupling 
Table 1 Comparison of the catalytic activity of $\mathrm{Pd} / \mathrm{CuFe}_{2} \mathrm{O}_{4}$ nanowires with other reported recent catalysts for Suzuki couplings

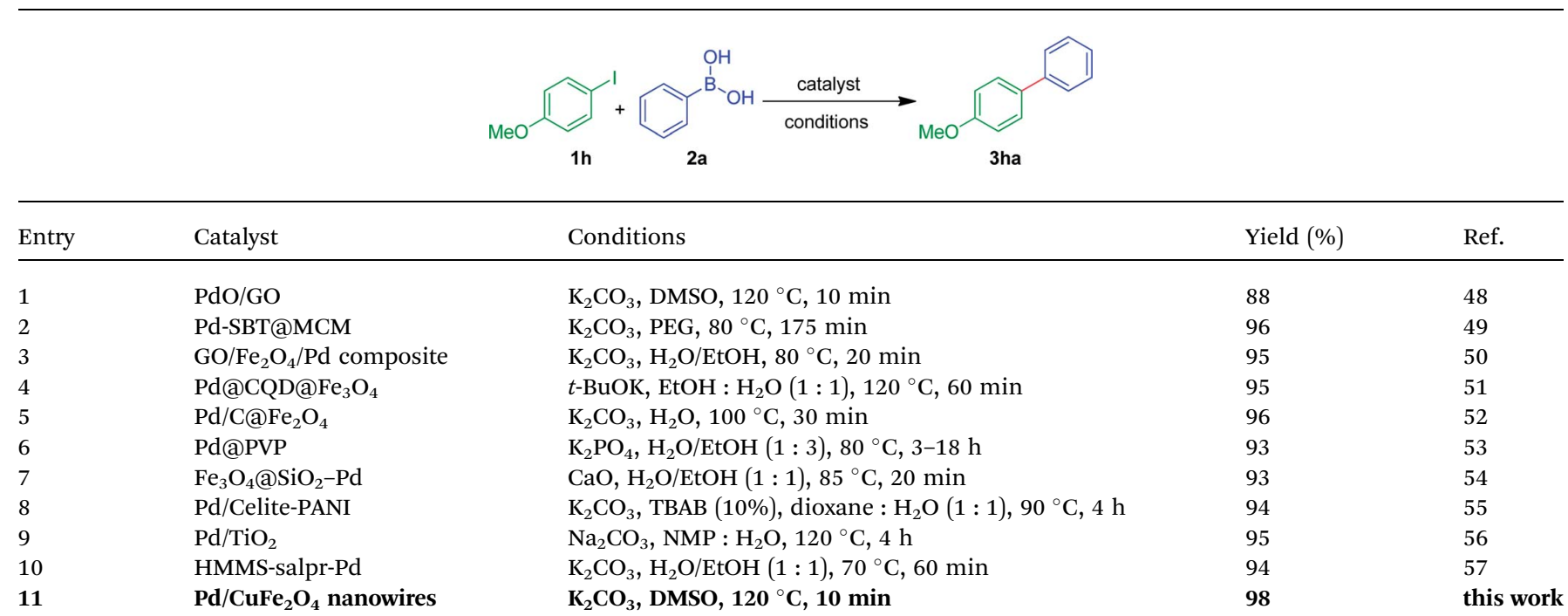

Table 2 Optimization studies for the formation of biphenyl 3ha ${ }^{a}$

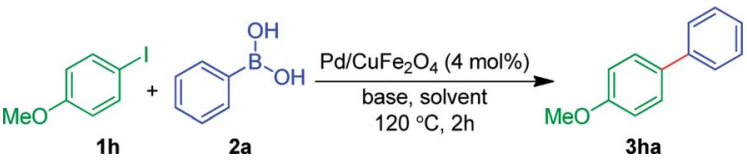

\begin{tabular}{llll}
\hline Entry & Base & Solvent & Yield $^{b} \mathbf{3 a a}(\%)$ \\
\hline $\mathbf{1}$ & $\mathbf{K}_{2} \mathrm{CO}_{3}$ & DMSO & $\mathbf{9 8}$ \\
2 & $\mathrm{~K}_{2} \mathrm{CO}_{3}$ & DMF & 95 \\
3 & $\mathrm{~K}_{2} \mathrm{CO}_{3}$ & DMA & 67 \\
4 & $\mathrm{~K}_{2} \mathrm{CO}_{3}$ & Toluene & 52 \\
5 & $\mathrm{~K}_{2} \mathrm{CO}_{3}$ & 1,4-Dioxane & 76 \\
6 & $\mathrm{~K}_{2} \mathrm{CO}_{3}$ & THF & 72 \\
7 & $\mathrm{~K}_{2} \mathrm{CO}_{3}$ & Acetonitrile & 63 \\
8 & $\mathrm{Cs}_{2} \mathrm{CO}_{3}$ & DMSO & 67 \\
9 & $\mathrm{~K}_{3} \mathrm{PO}_{4}$ & DMSO & 40 \\
10 & $\mathrm{NaOH}$ & DMSO & 31
\end{tabular}

${ }^{a}$ Reaction conditions: aryl iodides $\mathbf{1 h}(0.25 \mathrm{mmol})$, arylboronic acid $\mathbf{2 a}$ $(0.5 \mathrm{mmol}), \mathrm{Pd} / \mathrm{CuFe}_{2} \mathrm{O}_{4}(4 \mathrm{~mol} \%)$, base $(0.5 \mathrm{mmol})$ and solvent $(1 \mathrm{~mL})$ at $120{ }^{\circ} \mathrm{C} .{ }^{b}$ Isolated yields of product 3 ha.

reactions was shown in Table 1 . As shown in Table 1 , most of the Pd supported nanocatalysts produces the yields $88-96 \%$ (Table 1, entries 1-10). Whereas, with our catalyst $\mathrm{Pd} / \mathrm{CuFe}_{2} \mathrm{O}_{4}$ nanowires we got near quantitative yields (98\%) (Table 2, entry 11).

\section{Results \& discussion}

To begin with, the optimization of Suzuki-Miyaura coupling was planned. For this purpose, 4-methoxy iodobenzene $\mathbf{1 h}$ and phenylboronic acid 2a were chosen as the model substrates. Recently, we reported that $\mathrm{Pd} / \mathrm{CuFe}_{2} \mathrm{O}_{4}$ nanowires showed the best catalytic activity for Heck couplings. ${ }^{47}$ Thus, the reaction was carried out between 4-methoxy iodobenzene $\mathbf{1 h}$ and phenylboronic acid $2 \mathrm{a}$ in the presence of $\mathrm{Pd} / \mathrm{CuFe}_{2} \mathrm{O}_{4}$ nanowires (4 mole\%), $\mathrm{K}_{2} \mathrm{CO}_{3}$ (2 equiv.) and in DMSO $(1 \mathrm{~mL})$ at $120^{\circ} \mathrm{C}$ for $2 \mathrm{~h}$. Gratifyingly, the reaction was quite successful and furnished the biaryl product $3 \mathbf{h a}$, in near quantitative yield (Table 2, entry 1). On the other hand, other solvents, such as DMF, DMA, toluene, 1,4-dioxane, THF and acetonitrile were inferior (Table 2 , entries 2 to 7 ). While the reaction gave fair, moderate and poor yields of the product $3 \mathrm{ha}$ with other bases, such as $\mathrm{Cs}_{2} \mathrm{CO}_{3}$, $\mathrm{K}_{3} \mathrm{PO}_{4}$, and $\mathrm{NaOH}$ respectively (Table 2, entries 8 to 10).

Further to optimize the mol\% of the $\mathrm{Pd} / \mathrm{CuFe}_{2} \mathrm{O}_{4}$ catalyst, for the formation of $\mathbf{3 h a}$, the reaction was performed between 4 methoxy iodobenzene $\mathbf{1 h}$ and phenylboronic acid 2a with $0,1,2$, $4,6,8$, and $10 \mathrm{~mol} \%$ of $\mathrm{Pd}$ in $\mathrm{Pd} / \mathrm{CuFe}_{2} \mathrm{O}_{4}$, under standard conditions. Among all, it was observed that the reaction yields were more or less same with $\geq 4 \mathrm{~mol} \%$ of $\mathrm{Pd}$ in $\mathrm{Pd} / \mathrm{CuFe}_{2} \mathrm{O}_{4}$ (Fig. 1). Thus it was concluded that the $4 \mathrm{~mol} \%$ of Pd was an optimal load to drive the reaction.

With these best conditions in hand, the scope was extended for the Suzuki-Miyaura coupling with various iodoarenes 1a-l and arylboronic acids $\mathbf{2 a - d}$. Gratifyingly, the reaction was found to be amenable and afforded the corresponding biaryls 3aa-lb, in fair to near quantitative yields (Table 3). Interestingly, the reaction was successful with simple iodobenzene $\mathbf{1 a}$ and amenable with abroad range of functional groups (COOMe, $\mathrm{NO}_{2}$, OMe, $\mathrm{F} \& \mathrm{Cl}$ ) on aromatic ring $\mathbf{1} \mathbf{b}-\mathbf{j}$, which reveals a wide functional group tolerance of this reaction. Notably, heteroaromatic iodide $\mathbf{1 1}$, gave the products $\mathbf{3 l b}$, in excellent yield. Significantly, protecting group free iodopyridine 1k was also tolerable and afforded the products $\mathbf{3 k a - k c}$ (Table 3). Interestingly, the reaction was also amenable to simple arylboronic acids 2 bearing broad range of functional moieties on the aromatic ring [i.e. OMe, $\mathrm{F}$ and $\mathrm{Cl}$, (Table 3)]. To demonstrate the utility of the strategy, the Suzuki coupling reaction was explored with bromoarenes 1s-u with simple boronic acid 2a, under established conditions. Gratifyingly, biphenyls 3aa, 3da and 3ha were isolated in $82 \%, 70 \%$ and $68 \%$ yields (Table 3 ), respectively. Which ascertains the usefulness of $\mathrm{Pd}(0) / \mathrm{CuFe}_{2} \mathrm{O}_{4}$ 

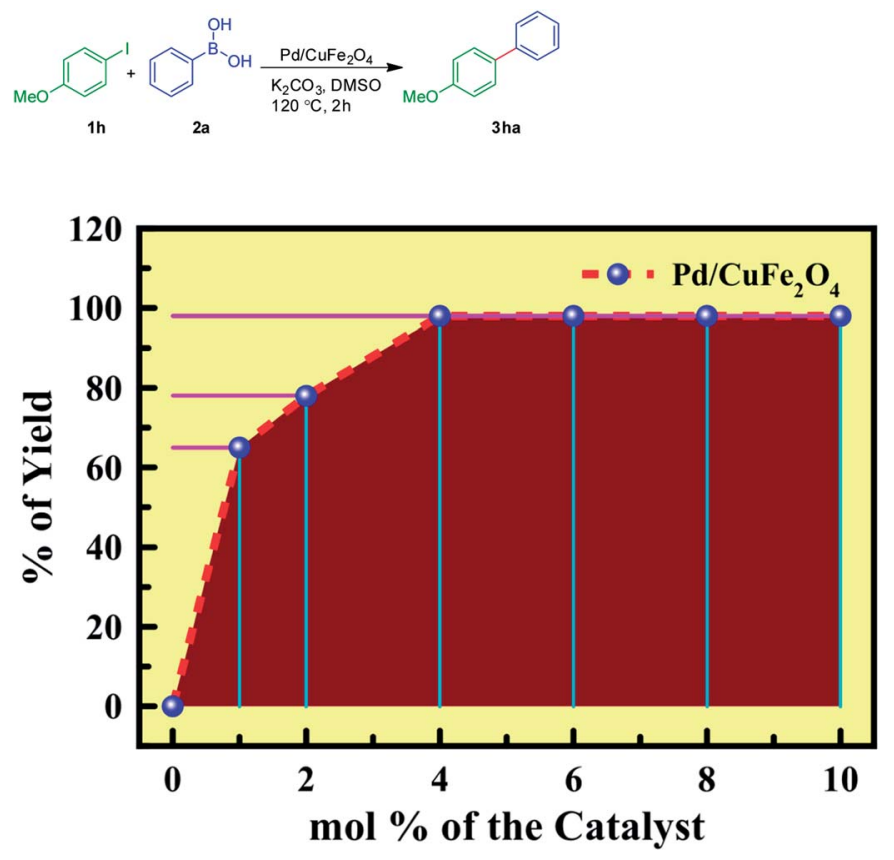

Fig. 1 Optimization of loading the catalyst for Suzuki-coupling reaction.

nanowires catalyst. Whereas the coupling with chlorobenzene $\mathbf{1 v}$ and meta-chloronitrobenzene $\mathbf{1 w}$ as reacting partners with the boronic acid 2a, furnished the desired biaryls 3aa and 3da in poor yields ( $25 \% \& 27 \%$ respectively, Table 3 ). It is noteworthy to mention that in case of $\mathbf{1 v}$ and $\mathbf{1 w}$, the homo coupling of boronic acid $2 \mathrm{a}$ was also noticed. In addition, the chloroarenes $1 \mathbf{v}$ and $1 \mathbf{w}$ were not completely consumed even after $24 \mathrm{~h}$.

The recovery of the catalyst was done by centrifugation and washing with ethyl acetate and acetone followed by drying in a hot air oven at $60{ }^{\circ} \mathrm{C}$ for $12 \mathrm{~h}$. The recovered $\mathrm{Pd} / \mathrm{CuFe}_{2} \mathrm{O}_{4}$ nanowires catalyst was then subjected to the next catalytic cycles. It is worth mentioning that the catalyst retains its activity, which is evident with nearly no loss of activity even after fifth reaction cycle (Fig. 2). The marginal loss of activity after the fifth cycle $(<3 \%)$ may be due to loss of some amount of the catalyst during the recovery of $\mathrm{Pd} / \mathrm{CuFe}_{2} \mathrm{O}_{4}$ nanowires. The catalyst was recycled five times without an appreciable change in the product 3 ha yield, under the established conditions at $120^{\circ} \mathrm{C}$. Thus, based on the above results it is confirmed that $\mathrm{Pd} /$ $\mathrm{CuFe}_{2} \mathrm{O}_{4}$ nanowires catalyst is stable enough and can be reused.

\section{The relation between catalytic properties and structure of $\mathrm{Pd} /$ $\mathrm{CuFe}_{2} \mathrm{O}_{4}$ nanowires}

The mechanism for the relation between catalytic properties (Suzuki coupling reaction) and structure of $\mathrm{Pd} / \mathrm{CuFe}_{2} \mathrm{O}_{4}$ nanowires is shown in Scheme 1. The first step would be the oxidative addition of $\mathrm{Pd}(0) / \mathrm{CuFe}_{2} \mathrm{O}_{4}$ nanowires to the 4-methoxy iodobenzene $1 \mathbf{h}$ to form $\mathrm{Pd}$ (II) species $\mathbf{A}$. In most cases the oxidative addition is the rate determining step of a catalytic cycle. During this step, the Pd is oxidized from $\operatorname{Pd}(0)$ to $\operatorname{Pd}(\mathrm{II})$. Further, the reaction with base gives the intermediate $\mathbf{B}$, which on coupling with the activated boronic acid derivative $\mathbf{C}$ (produced by reaction of the boronic acid 2a with $\mathrm{K}_{2} \mathrm{CO}_{3}$ base), gives transmetalation complex D. Finally, the reductive elimination of D affords the coupled product 3 ha restores the active $\operatorname{Pd}(0)$ / $\mathrm{CuFe}_{2} \mathrm{O}_{4}$ nanowires, thus completes the catalytic cycle.

After successful synthesis of biaryls using Suzuki-Miyaura coupling, in order to check the efficiency of the $\mathrm{Pd} / \mathrm{CuFe}_{2} \mathrm{O}_{4}$ nanowires catalyst, we aimed at Sonogashira coupling between iodoarenes and arylacetylenes. Therefore, initially, the reaction was explored between 2-amino iodobenzene $\mathbf{1 m}$ and phenylacetylene 4a, under established conditions as above (see; Table 2 , entry 1). The reaction was quite successful and furnished the 2 -amino diphenylacetylene product $5 \mathrm{ma}$, in good yield (Table 4 , entry 1). On the other hand, the reaction was found to be inferior with the other solvents, such as DMF, DMA, toluene, 1,4dioxane, THF and acetonitrile (Table 4, entries 2 to 7 ). While the reaction with bases $\mathrm{Cs}_{2} \mathrm{CO}_{3}$ and $\mathrm{KOH}$ gave moderate yields of the product $5 \mathrm{ma}$ (Table 4 , entries 8 and 9).

With the above optimized conditions, for Sonogashira coupling, to demonstrate the utility of the strategy, the activity of $\mathrm{Pd} / \mathrm{CuFe}_{2} \mathrm{O}_{4}$ catalyst was assessed for the reaction between iodoarenes $\mathbf{1 a}-\mathbf{q}$ and phenylacetylene $\mathbf{4 a}$. The results of the catalytic reactions are as depicted in Table 5 , which showed broad substrate scope and delivered the corresponding internal acetylenes 5aa-qa, in fair to very good yields. For example, iodoarenes bearing electron-withdrawing groups (meta-COOMe, para-COOMe, meta- $\mathrm{NO}_{2}$ ) were found to be smooth and afforded the products (5ba, 5ca \& 5da) moderate yields (Table 5). In addition, the reaction was quite successful with electron releasing groups as well (5fa, 5ga \& 5ha, Table 5). Notably, the reaction was tolerable to protecting group free $\mathrm{NH}_{2}$ moiety on pyridine ring (5ka, Table 5). To our delight, 2-iodobenzylalcohol 
Table 3 Synthesis of biphenyls with aryl iodide and arylboronic acid ${ }^{a, b}$<smiles>[R][R]1ccc(-c2cc[nH]c2)cc1</smiles>

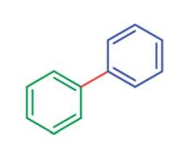

3aa $\left(91 \%, 82 \%^{c}, 25 \%^{d}\right)$<smiles>COC(=O)c1ccccc1-c1ccccc1</smiles>

3ba $(75 \%)$

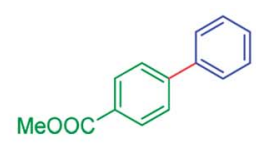

3ca $(80 \%)$

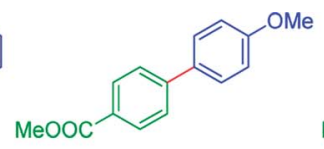

$3 \mathrm{cb}(98 \%)$

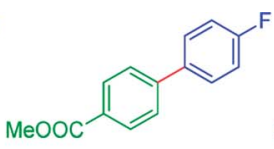

3 cc $(80 \%)$<smiles>COC(=O)c1ccc(-c2ccc(Cl)cc2)cc1</smiles>

$3 \mathrm{~cd}(82 \%)$<smiles>COc1ccc(-c2cccc([N+](=O)[O-])c2)cc1</smiles>

$3 \mathrm{db}(96 \%)$<smiles>COc1ccc(-c2ccccc2)cc1</smiles>

3ha $\left(98 \%, 68 \%{ }^{\circ}\right)$<smiles>COc1ccc(-c2ccc(F)cc2)cc1</smiles>

$3 i b(94 \%)$<smiles>COc1ccc(-c2cccs2)cc1</smiles>

3lb $(91 \%)$<smiles>O=[N+]([O-])c1cccc(-c2ccc(F)cc2)c1</smiles>

3dc $(99 \%)$

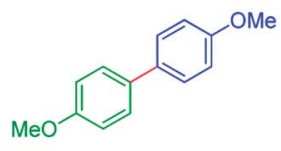

$3 \mathrm{hb}(98 \%)$

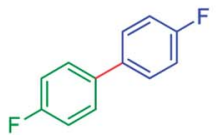

3ic $(82 \%)$<smiles>COc1ccc(-c2ccc(Cl)cc2)cc1</smiles><smiles>O=[N+]([O-])c1cccc(-c2ccc(Cl)cc2)c1</smiles>

3dd (97\%)<smiles>COc1cccc(-c2ccc(F)cc2)c1</smiles>

3gc $(99 \%)$<smiles>Clc1ccc(-c2ccc(Cl)cc2)cc1</smiles>

3jd (78\%)<smiles>O=[N+]([O-])c1cccc(-c2ccccc2)c1</smiles>

3da $\left(74 \%, 70 \%^{c}, 27 \%^{d}\right)$<smiles>COc1ccc(-c2ccc(I)cc2)cc1</smiles>

3hc $(89 \%)$<smiles>Nc1ccc(-c2ccccc2)cn1</smiles>

3ka (65\%)<smiles>COc1ccccc1-c1ccccc1</smiles>

3fa (98\%)<smiles>COc1cccc(-c2ccc(Cl)cc2)c1</smiles>

3gd (88\%)<smiles>COc1ccc(-c2ccc(N)nc2)cc1</smiles>

$3 \mathrm{~kb}(97 \%)$<smiles>COc1cccc(-c2ccccc2)c1</smiles>

3ga $(90 \%)$<smiles>COc1ccc(-c2ccc(Cl)cc2)cc1</smiles>

3hd $(72 \%)$<smiles>Nc1ccc(-c2ccc(F)cc2)cn1</smiles>

3kc (97\%)

${ }^{a}$ Reaction conditions: aryl iodides $(0.25 \mathrm{mmol})$, arylboronic acid $(0.5 \mathrm{mmol}), \mathrm{Pd} / \mathrm{CuFe}_{2} \mathrm{O}_{4}(4 \mathrm{~mol} \%), \mathrm{K}_{2} \mathrm{CO}_{3}(0.5 \mathrm{mmol})$ and $\mathrm{DMSO}(1 \mathrm{~mL})$ at $120{ }^{\circ} \mathrm{C}$. ${ }^{b}$ Isolated yields of chromatographically pure products 3aa-lb. ${ }^{c}$ Isolated yields of products when bromoarenes 1 s-u were used. ${ }^{d}$ Isolated yields of products when chloroarenes $1 \mathbf{v}-\mathbf{w}$ were used.

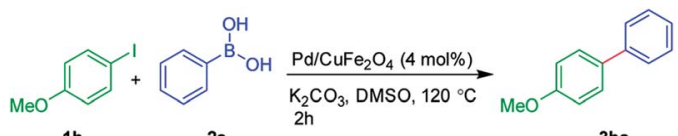

$2 a$

3ha

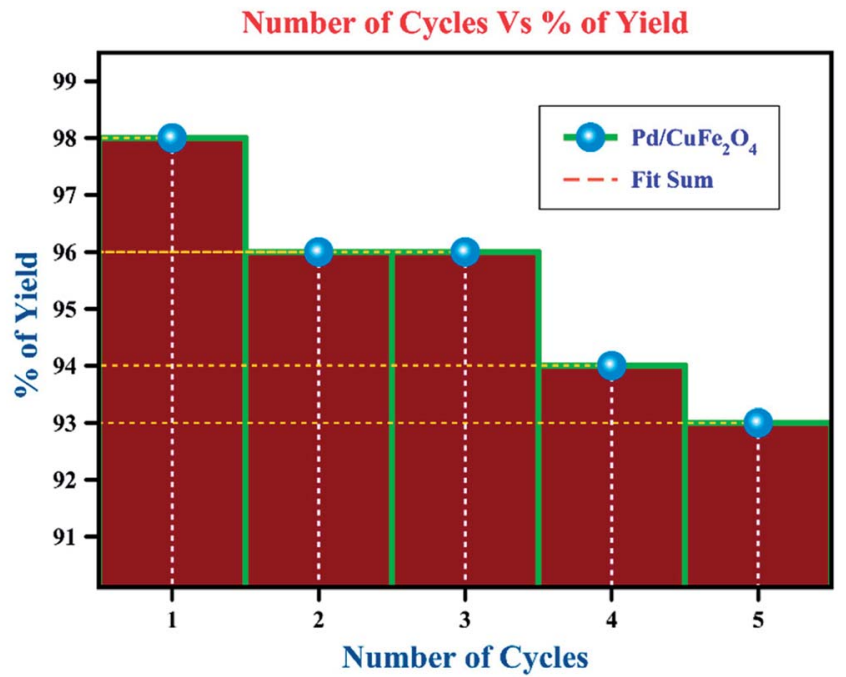

Fig. 2 Recyclability of the catalyst $\mathrm{Pd} / \mathrm{CuFe}_{2} \mathrm{O}_{4}$ nanowires in Suzuki reaction. 


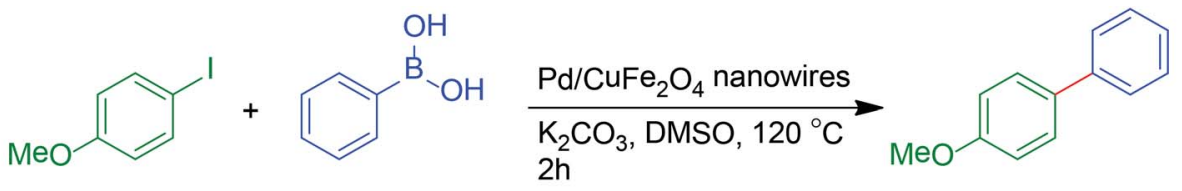

$1 \mathrm{~h}$

2a

3ha

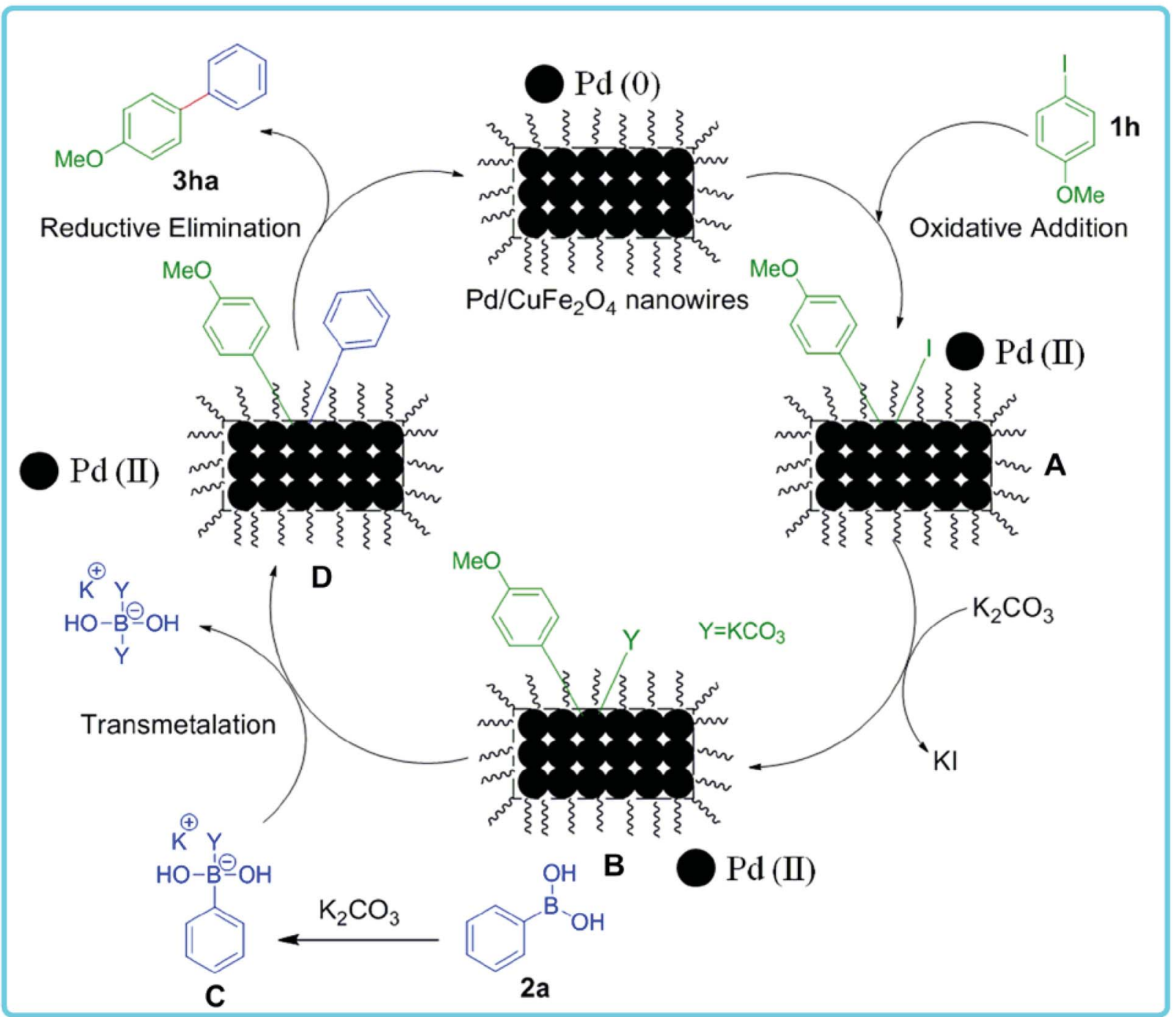

Scheme 1 The mechanism for the relation between catalytic properties (Suzuki coupling reaction) and structure of $\mathrm{Pd} / \mathrm{CuFe}_{2} \mathrm{O}_{4}$ nanowires.

2n coupled with phenylacetylene $4 \mathbf{a}$ and gave the product 5na, in very good yield (Table 5). Further, we have explored Sonogashira coupling between bromobenzene 1s and phenylacetylene 4a. Notably, the reaction was smooth and yielded diphenylacetylene 5aa, in yields 68\%. Even the reaction was also successful meta-bromonitrobenzene $\mathbf{1 t}$ and para-methoxybromobenzene $\mathbf{1 u}$ with $\mathbf{4 a}$. While, the reaction is somewhat sluggish with chloroarenes. Therefore, the present catalyst seems to be active enough and could promote the reactions with bromoarenes as well. To further check the selectivity of the process, it was planned to test the substituent susceptibility. Thus, the reaction was conducted with 1-chloro-4-iodobenzene $\mathbf{1 j}$ in the presence of phenylacetylene $\mathbf{4 a}$, in very good yields (Table 5). To our delight, the reaction was found to be smooth and selective and gave the product $\mathbf{5 j b}$, in which relatively more reactive iodo substituent was selectively involved in the coupling reaction. It is worth mentioning that the reaction with ethyl propiolate as coupling partner, did not lead to any product and only starting materials were recovered. This may be due to the fact that less nucleophilicity of acetylenic $\beta$-carbon of ethyl propiolate.

Benzofurans are ubiquitous oxygen-containing heterocyclic motifs that constitute many natural products, pharmaceuticals, biologically important compounds and organic materials. In this context, many synthetic strategies have been established for their synthesis. Notably, transition metal-catalyzed $\left(\mathrm{Pd},{ }^{58-66}\right.$ $\mathrm{Rh},{ }^{67} \mathrm{Ru},{ }^{68-71} \mathrm{Ir}^{72} \mathrm{Au}^{73}$ and $\mathrm{Cu}^{74-76}$ ) annulations proved to be powerful strategies for the synthesis of benzofurans. Quite 
Table 4 Optimization studies for the formation of 2-(phenyl ethynyl) aniline $5 \mathrm{ma}^{a}$

\begin{tabular}{|c|c|c|c|c|}
\hline \multicolumn{2}{|c|}{$1 \mathrm{~m}$} & $\left.\begin{array}{c}\mathrm{Pd} / \mathrm{CuFe}_{2} \mathrm{O} \\
(4 \mathrm{~mol} \%)\end{array}\right)$ & \multicolumn{2}{|c|}{$5 \mathrm{ma}$} \\
\hline Entry & Base & Solvent & Yield $(5 \mathrm{ma})^{b}$ & Time (h) \\
\hline 1 & $\mathrm{~K}_{2} \mathrm{CO}_{3}$ & DMSO & 75 & 12 \\
\hline 2 & $\mathrm{~K}_{2} \mathrm{CO}_{3}$ & DMF & 60 & 12 \\
\hline 3 & $\mathrm{~K}_{2} \mathrm{CO}_{3}$ & DMA & 35 & 24 \\
\hline 4 & $\mathrm{~K}_{2} \mathrm{CO}_{3}$ & Toluene & $-^{c}$ & 48 \\
\hline 5 & $\mathrm{~K}_{2} \mathrm{CO}_{3}$ & 1,4-Dioxane & 36 & 24 \\
\hline 6 & $\mathrm{~K}_{2} \mathrm{CO}_{3}$ & THF & 30 & 24 \\
\hline 7 & $\mathrm{~K}_{2} \mathrm{CO}_{3}$ & $\mathrm{CH}_{3} \mathrm{CN}$ & 32 & 24 \\
\hline 8 & $\mathrm{Cs}_{2} \mathrm{CO}_{3}$ & DMSO & 55 & 12 \\
\hline 9 & KOH & DMSO & 48 & 12 \\
\hline
\end{tabular}

interestingly, when 2-iodophenols $\mathbf{1 n}-\mathbf{r}$ were treated with terminal acetylenes $\mathbf{4 a - i}$, benzofurans were obtained as the products (Table 6). For example, the reaction was amenable to different arylacetylenes (4a, 4c \& 4d) and furnished the corresponding benzofurans 7ra-rd (Table 6). Notably, the reaction was also successful with terminal alkyl acetylenes $\mathbf{4 e - h}$ and
Table 6 Synthesis of benzofurans 7ra-ri from 2-iodophenols 1n-r and aryl alkynes $4 a-i^{a, b}$

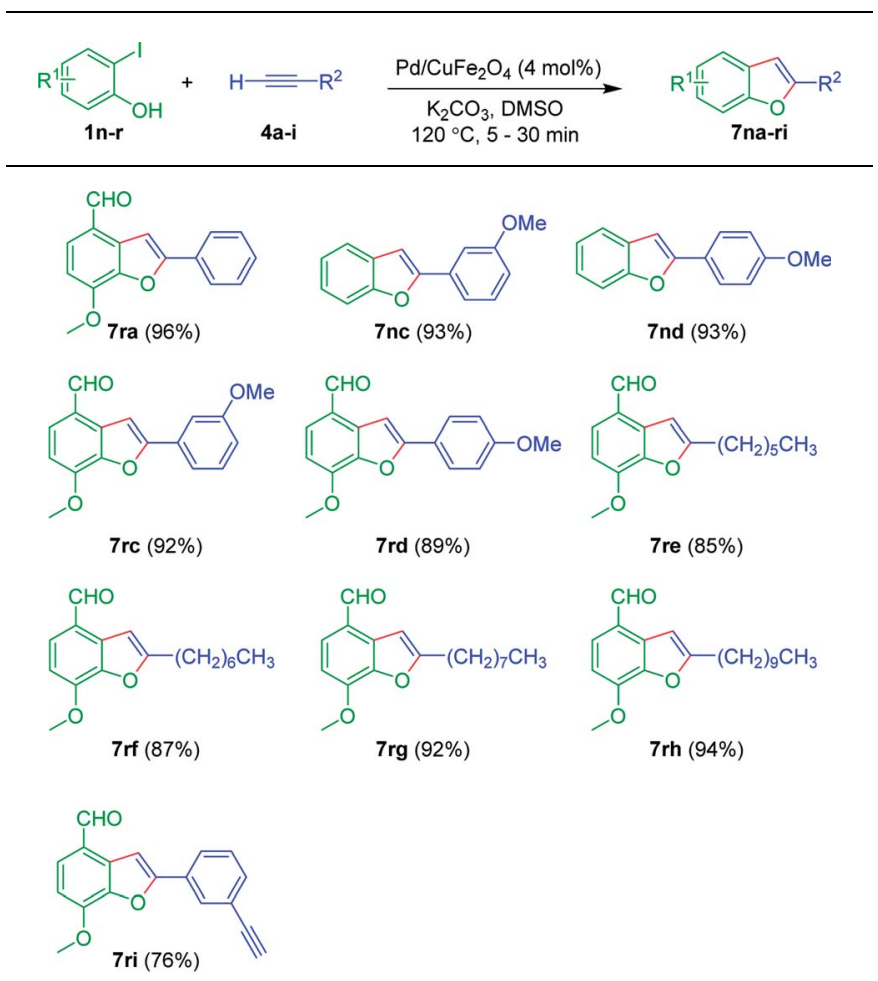

${ }^{a}$ Reaction conditions: 2 -iodophenols $\mathbf{1 n}-\mathbf{r}(0.5 \mathrm{mmol})$, aryl alkynes $4 \mathrm{a}-\mathbf{i}$ $(0.5 \mathrm{mmol}), \mathrm{Pd} / \mathrm{CuFe}_{2} \mathrm{O}_{4}$ nanowires $(4 \mathrm{~mol} \%), \mathrm{K}_{2} \mathrm{CO}_{3}(1 \mathrm{mmol})$ and DMSO $(1 \mathrm{~mL})$ at $120{ }^{\circ} \mathrm{C}^{b}$ Isolated yields of product 7na-ri.

Table 5 The $\mathrm{Pd} / \mathrm{CuFe}_{2} \mathrm{O}_{4}$ nanowires catalyzed Sonogashira coupling reaction between iodoarenes $1 \mathrm{a}-\mathrm{q}$ and phenylacetylene $4 \mathrm{a}^{a, b}$

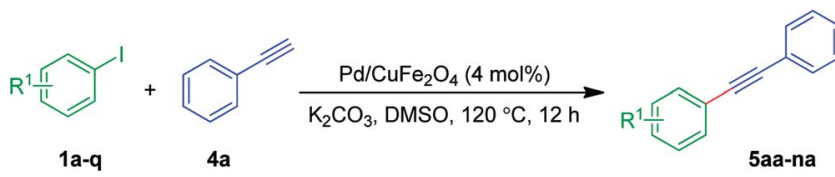

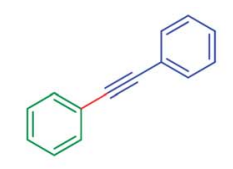

5aa $\left(78 \%, 68 \%,{ }^{c} 20 \%{ }^{d}\right)$

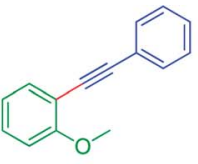

5fa (85\%)

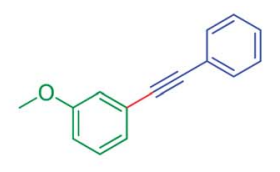

5 ga $(76 \%)$

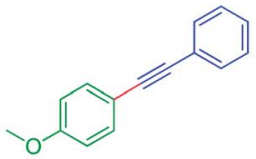

5ha $\left(84 \%, 63 \%^{c}\right)$<smiles>C(=C/c1ccccc1NCc1ccccc1)\c1ccccc1</smiles>

5ma $(75 \%)$<smiles>Nc1ccc(C#Cc2ccccc2)cn1</smiles>

5ka (68\%)<smiles>COC(=O)c1cccc(C#Cc2ccccc2)c1</smiles>

5ba (68\%)

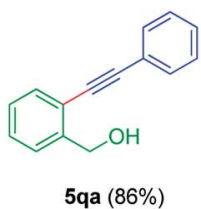

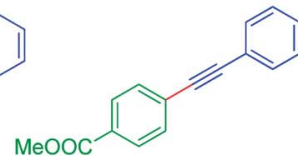

5ca $(72 \%)$<smiles>CC(C)(C)[13CH3]</smiles>

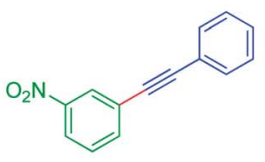

5da $\left(65 \%, 60 \%,{ }^{c} 23 \%{ }^{d}\right)$

\footnotetext{
${ }^{a}$ Reaction conditions: aryl iodides $1 \mathrm{1a}-\mathbf{q}(0.5 \mathrm{mmol})$, phenylacetylene $4 \mathbf{4 a}(1 \mathrm{mmol}), \mathrm{Pd} / \mathrm{CuFe}_{2} \mathrm{O}_{4}(4 \mathrm{~mol} \%), \mathrm{K}_{2} \mathrm{CO}_{3}(1 \mathrm{mmol})$ and $\mathrm{DMSO}(1 \mathrm{~mL})$ at $120{ }^{\circ} \mathrm{C} .{ }^{b}$ Isolated yields of product 5aa-5qa. ${ }^{c}$ Isolated yields of products when bromoarenes $1 \mathrm{~s}-\mathbf{u}$ were used. ${ }^{d}$ Isolated yields of products when chloroarenes $1 \mathbf{v}-\mathbf{w}$ were used.
} 
Table 7 Attempting for Sonogashira reaction between iodoarenes $1 \mathrm{~m}-\mathrm{n}$ and ethyl propiolate $4 \mathrm{~b}^{a, b}$

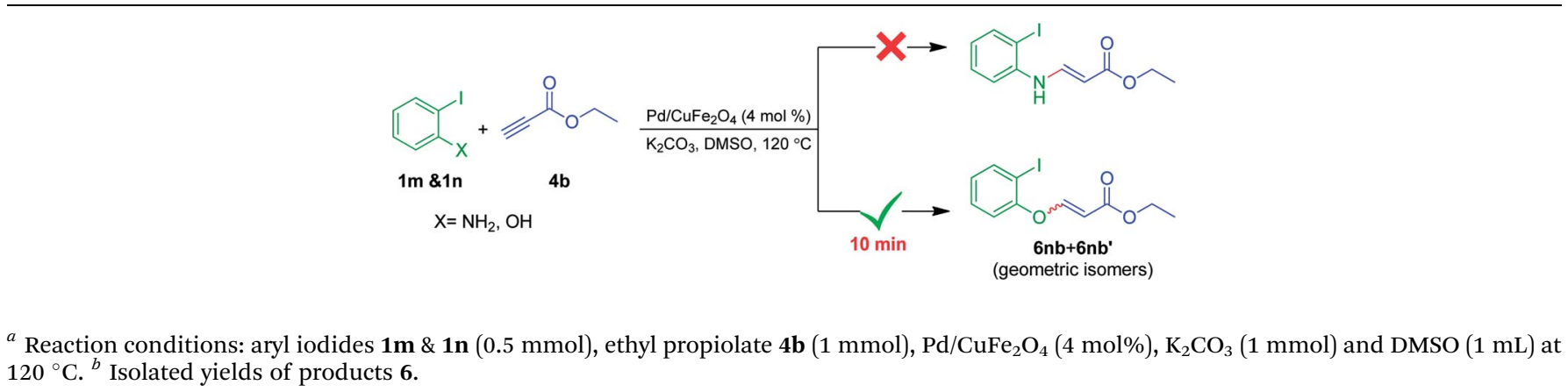
$120{ }^{\circ} \mathrm{C} .{ }^{b}$ Isolated yields of products 6 .

Table 8 Screening conditions for the formation of $6 \mathrm{nb}+6 \mathrm{nb}^{\prime}$ from iodophenol $1 \mathrm{n}$ and ethyl propiolate $4 \mathrm{~b}^{a, b}$

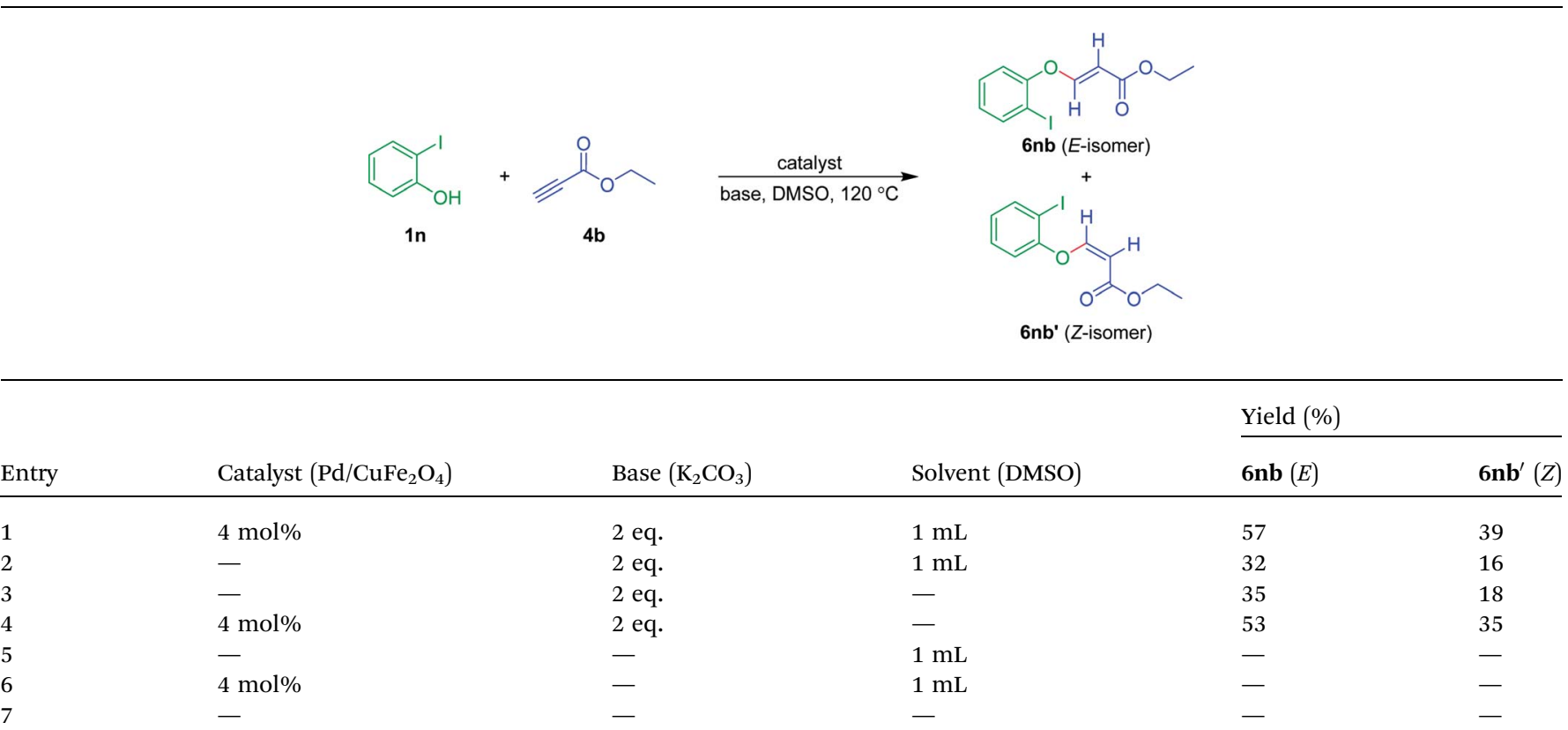

${ }^{a}$ Reaction conditions: aryl iodides $1 \mathrm{n}(0.5 \mathrm{mmol})$, ethyl propiolate $4 \mathbf{b}(1 \mathrm{mmol}), \mathrm{Pd} / \mathrm{CuFe}_{2} \mathrm{O}_{4}(4 \mathrm{~mol} \%), \mathrm{K}_{2} \mathrm{CO}{ }_{3}(1 \mathrm{mmol})$ and DMSO $(1 \mathrm{~mL})$ at $120{ }^{\circ} \mathrm{C}$.

${ }^{b}$ Isolated yields of products 6 .

afforded the benzofurans 7re-rh, in very good to excellent yields (Table 6). Significantly, the reaction was tolerable to the aldehyde functionality on the aromatic ring of 2-iodophenol derivative 1r. Significantly, 3-hydroxy-2-iodo-4-methoxybenzaldehyde 1r coupled with 1,3-diethynylbenzene $4 \mathbf{i}$, in which only one acetylene group was reacted and gave $7 \mathbf{r i}$ as an exclusive product (Table 6).

Moreover, to check the scope and generality of Sonogashira coupling, 2-iodophenol was treated with ethyl propiolate $\mathbf{4 b}$. Surprisingly, no Sonogashira product was formed; instead, Michael addition product $\mathbf{6 n b}$ was obtained as major diastereomer via nucleophilic attack of the hydroxyl group of phenol (Table 7). This sort of nucleophilic 1,4-addition of phenolic hydroxyl across the activated triple/double bonds is already established in the literature. ${ }^{77-79}$ Whereas, when 2-iodoaniline was reacted with ethyl propiolate $\mathbf{4 b}$, we could not observe any required product. The reaction was inconclusive from the TLC.
To understand the nature of the reaction and whether or not the palladium is necessary to drive this Michael addition reaction, the reaction was performed under varying conditions, as illustrated in Table 8. The reaction under standard conditions, furnished the product $\mathbf{6 n b}+\mathbf{6 n b} \mathbf{b}^{\prime}(57+39)$ (Table 8, entry 1$)$. The reaction was also successful without Pd-catalyst, but with the base and solvent, albeit there was a drop in the yields $\left[\mathbf{6} \mathbf{n b}+\mathbf{6} \mathbf{n} \mathbf{b}^{\prime}\right.$ $(32+16)$, Table 8 , entry 2$]$. In addition, the reaction was smooth, under neat conditions with base and without catalyst $\left[\mathbf{6 n b}+\mathbf{6} \mathbf{n b}^{\prime}\right.$ $(35+18)$, Table 8 , entry 3]. While the yield of the product was good with both catalyst and base and without solvent $\left[\mathbf{6 n b}+\mathbf{6 n} \mathbf{n b}^{\prime}\right.$ $(53+35)$, Table 8 , entry 4]. Only with solvent and without base and catalyst, no progress was noted (Table 8, entry 5). Similarly, with the catalyst and solvent, without base, no progress was seen (Table 8, entry 6). The reaction did not proceed without the catalyst, base and solvent (Table 8, entry 7). 
Table 9 Attempting for Sonogashira reaction between iodoarenes and ethyl propiolate $4 \mathrm{~b}^{a, b}$

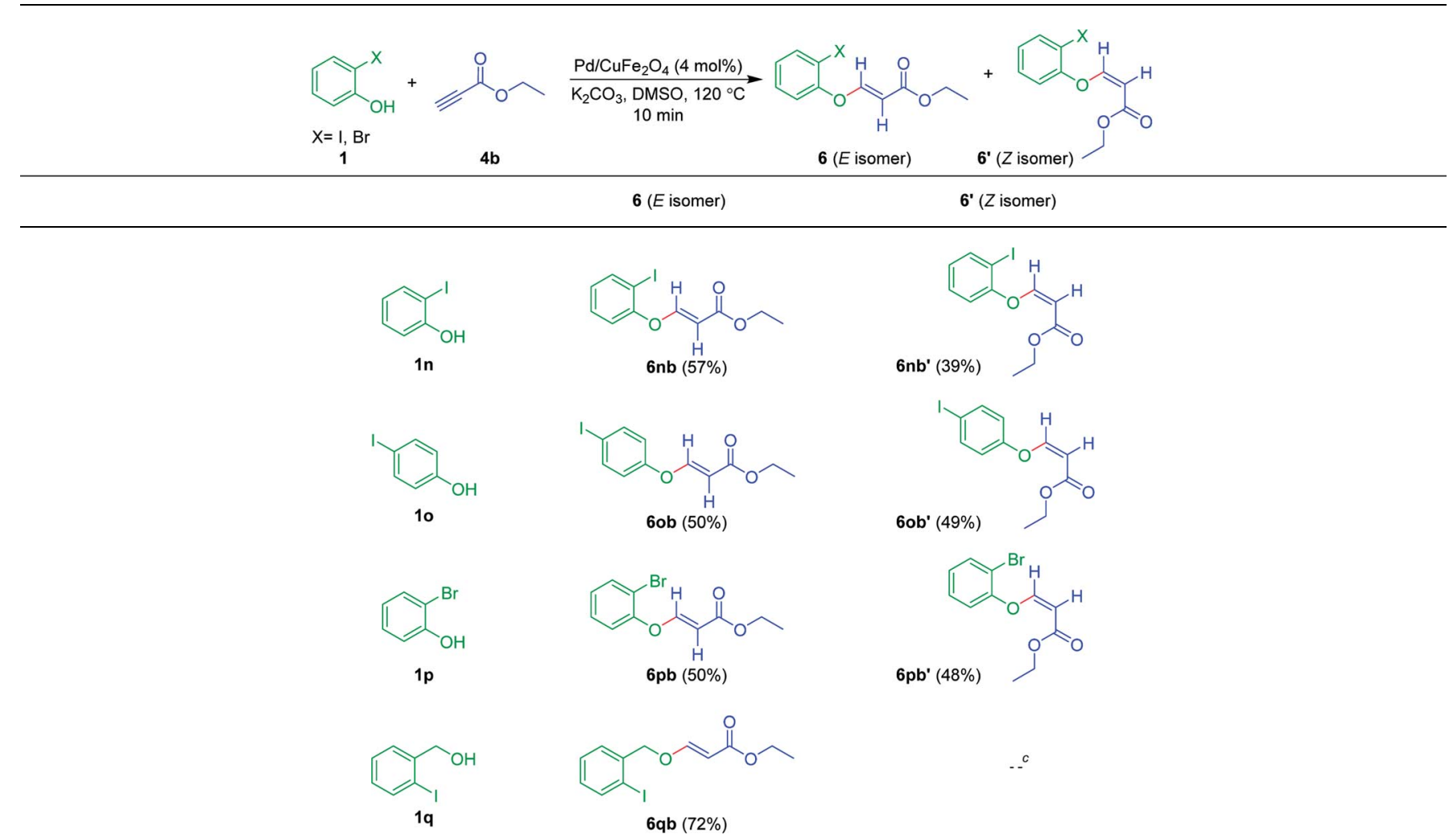

\footnotetext{
${ }^{a}$ Reaction conditions: aryl iodides $\mathbf{1 n}-\mathbf{q}(0.5 \mathrm{mmol})$, ethyl propiolate $\mathbf{4 b}(1 \mathrm{mmol}), \mathrm{Pd} / \mathrm{CuFe}_{2} \mathrm{O}_{4}(4 \mathrm{~mol} \%), \mathrm{K}_{2} \mathrm{CO}_{3}(1 \mathrm{mmol})$ and DMSO $(1 \mathrm{~mL})$ at $120{ }^{\circ} \mathrm{C}^{b}{ }^{b}$ Isolated yields of products $6 .{ }^{c}$ Only single $E$-isomer $\mathbf{6 q b}$ was formed.
}

To further confirm this sort of reactivity, the reaction was explored with different halophenols (1n, 1o, 1p \& 1q) with ethyl propiolate $\mathbf{4 b}$, under standard reaction conditions. As anticipated, furnished the corresponding arylvinyl ethers as $Z$ and $E$ diastereomeric mixture, as minor and major isomers, respectively (Table 9). Surprisingly, when 2-iodobenzylalcohol 1q was used as the nucleophile, exclusively, gave the $E$ isomer in $72 \%$ yield (Table 9).

\section{Conclusions}

In summary, we have demonstrated a facile route for the synthesis of biphenyls, diphenylacetylene and 2-aryl/alkyl benzofuran derivatives via ligand-free Suzuki, Sonogashira coupling reactions using the catalyst $\mathrm{Pd} / \mathrm{CuFe}_{2} \mathrm{O}_{4}$ nanowires. The Suzuki cross-coupling reaction furnished the biphenyls with excellent to near quantitative yields. Further, the optimized conditions were applied for Sonogashira coupling followed by the intramolecular nucleophilic attack for the formation benzofurans. It was also demonstrated for the unusual formation arylvinyl ethers via nucleophilic attack of the hydroxyl group of phenol onto the triple bond of ethyl propiolate.

\section{Conflicts of interest}

There is no conflict of interest.

\section{Acknowledgements}

B. L. Narayana would like to thanks to University Grant Commission (UGC), New Delhi, for awarding Junior \& Senior Research Fellowship (JRF \& SRF).

\section{References}

1 R. Hudson, Y. Feng, R. S. Varma and A. Moores, Green Chem., 2014, 16, 4493-4505.

2 R. S. Varma, Green Chem., 2014, 16, 2027-2041.

3 J. A. Gladysz, Chem. Rev., 2002, 102, 3215-3216.

4 D. Astruc, F. Lu and J. R. Aranzaes, Angew. Chem., Int. Ed., 2005, 44, 7852-7872.

5 M. B. Gawande, R. K. Pandey and R. V. Jayaram, Catal. Sci. Technol., 2012, 2, 1113-1125.

6 S. N. Shelke, S. R. Bankar, G. R. Mhaske, S. S. Kadam, D. K. Murade, S. B. Bhorkade and R. S. Varma, ACS Sustainable Chem. Eng., 2014, 2, 1699-1706.

7 M. B. Gawande, P. S. Branco, K. Parghi, J. J. Shrikhande, R. K. Pandey, C. A. A. ghumman, N. Bundaleski, O. Teodoro and R. V. Jayam, Catal. Sci. Technol., 2011, 1, 1653-1664.

8 G. A. Somorjai, H. Feri and J. Y. Park, J. Am. Chem. Soc., 2009, 131, 16589-16605. 
9 M. Beller, H. Fischer, K. Kuhlein, C. P. Reisinger and W. A. Herrmann, J. Organomet. Chem., 1996, 520, 257-259.

10 M. L. Kantam, S. Roy, M. Roy, B. Sreedhar and B. M. Choudary, Adv. Synth. Catal., 2005, 347, 2002-2008.

11 X. R. Ye, Y. H. Lin, C. M. Wang, M. H. Engelhard, Y. Wang and C. M. Wai, J. Mater. Chem., 2004, 14, 908-913.

12 B. Lakshminarayana, L. Mahendar, P. Ghosal, G. Satyanarayana and Ch. Subrahmanyam, ChemistrySelect, 2017, 2, 2703-2710.

13 R. Narayanan and M. A. El-Sayed, J. Am. Chem. Soc., 2003, 125, 8340-8347.

14 S. Shylesh, V. Schunemann and W. R. Thiel, Angew. Chem., Int. Ed., 2010, 49, 3428-3459.

15 K. H. Lee, B. Lee, K. R. Lee, M. H. Yi and N. H. Hur, Chem. Commun., 2012, 48, 4414-4416.

16 A. T. Nguyen, L. T. Pham, N. T. Phan and T. Truong, Catal. Sci. Technol., 2014, 4, 4281-4288.

17 N. Miyaura and A. Suzuki, Chem. Rev., 1995, 95, 2457-2483.

18 G. Ding, W. Wang, T. Jiang and B. Han, Green Chem., 2013, 15, 3396-3403.

19 C. C. Johansson Seechurn, M. O. Kitching, T. J. Colacot and V. Snieckus, Angew. Chem., Int. Ed., 2012, 51, 5062-5085.

20 L. Yin and J. Liebscher, Chem. Rev., 2007, 107, 133-173.

21 A. Fihri, M. Bouhrara, B. Nekoueishahraki, J. M. Basset and V. Polshettiwar, Chem. Soc. Rev., 2011, 40, 5181-5203.

22 K. C. Nicolaou, P. G. Bulger and D. Sarlah, Angew. Chem., Int. Ed., 2005, 44, 4442-4489.

23 A. Radadiya and A. Shah, Eur. J. Med. Chem., 2015, 97, 356376.

24 R. J. Nevagi, S. N. Dighe and S. N. Dighe, Eur. J. Med. Chem., 2015, 97, 561-581.

25 H. Khanam and Shamsuzzaman, Eur. J. Med. Chem., 2015, 97, 483-504.

26 P. Stehrer-Schmid and H. U. Wolf, Mutat. Res., Rev. Genet. Toxicol., 1995, 339, 61-72.

27 R. Naik, D. S. Harmalkar, X. Xu, K. Jang and K. Lee, Eur. J. Med. Chem., 2015, 90, 379-393.

28 J. Knoll, CNS Drug Rev., 2001, 7, 317-345.

29 M. J. Bosiak, M. Rakowiecki, A. Wolan, J. Szlachta, E. Stanek, D. Cycoń and K. Skupień, Dyes Pigm., 2015, 121, 79-87.

30 M. J. Bosiak, J. A. Jakubowska, K. B. Aleksandrzak, S. Kamiński, A. Kaczmarek-Kędziera, M. Ziegler-Borowska, D. Kędziera and J. Adams, Tetrahedron Lett., 2012, 53, 3923-3926.

31 M. J. Bosiak, M. Rakowiecki, K. J. Orłowska, D. Kędziera and J. Adams, Dyes Pigm., 2013, 99, 803-811.

32 K. Kadac, M. J. Bosiak and J. Nowaczyk, Synth. Met., 2012, 162, 1981-1986.

33 L. Duan, R. Fu, B. Zhang, W. Shi, S. Chen and Y. Wan, ACS Catal., 2016, 6, 1062-1074.

34 L. Mahendar and G. Satyanarayana, J. Org. Chem., 2015, 80, 7089-7098.

35 E. Speckmeier, C. Padié and K. Zeitler, Org. Lett., 2015, 17, 4818-4821.

36 S. C. Yin, Q. Zhou, X. Y. Zhao and L. X. Shao, J. Org. Chem., 2015, 80, 8916-8921.
37 R. Karmakar, P. Pahari and D. Mal, Chem. Rev., 2014, 114, 6213-6284.

38 L. De Luca, G. Giacomelli and G. Nieddu, J. Comb. Chem., 2008, 10, 517-520.

39 O. Miyata, N. Takeda and T. Naito, Org. Lett., 2004, 6, 17611763.

40 D. Rosario-Amorin, M. Gaboyard, R. Clerac, L. Vellutini, S. Nlate and K. Heuze, Chem.-Eur. J., 2012, 18, 3305-3315.

41 Y. Jang, J. Chung, S. Kim, S. W. Jun, B. H. Kim, D. W. Lee, B. M. Kim and T. Hyeon, Phys. Chem. Chem. Phys., 2011, 13, 2512-2516.

42 M. Y. Zhu and G. W. Diao, J. Phys. Chem. C, 2012, 116, 1626.

43 Y. T. Liao, L. S. He, J. Huang, J. Y. Zhang, L. Zhuang, H. Shen and C. Y. Su, ACS Appl. Mater. Interfaces, 2011, 2, 2333-2338.

44 M. Zeltner, A. Schatz, M. L. Hefti and W. J. Stark, J. Mater. Chem., 2011, 21, 2991-2996.

45 A. Schatz, T. R. Long, R. N. Grass, W. J. Stark, P. R. Hanson and O. Reiser, Adv. Funct. Mater., 2010, 20, 4323-4328.

46 R. Li, P. Zhang, Y. Huang, P. Zhang, H. Zhong and Q. Chen, J. Mater. Chem., 2012, 22, 22750-22755.

47 B. Lakshminarayana, L. Mahendar, P. Ghosal, B. Sreedhar, G. Satyanarayana and C. h. Subrahmanyam, New J. Chem., 2018, 42, 1646-1654.

48 B. Lakshminarayana, L. Mahendar, J. Chakraborty, G. Satyanarayana and C. h. Subrahmanyam, J. Chem. Sci., 2018, 130, 47.

49 M. Nikoorazm, A. Ghorbani-Choghamarani, M. Ghobadi and S. Massahi, Appl. Organomet. Chem., 2017, 31, e3848.

50 N. Seyedi, K. Saidi and H. Sheibani, Catal. Lett., 2018, 148, 277-288.

51 M. Gholinejad, F. Zareh and C. Nájera, Appl. Organomet. Chem., 2018, 32, 1-14.

52 R. N. Baig, M. N. Nadagouda and R. S. Varma, Green Chem., 2014, 16, 4333-4338.

53 F. Mäsing, H. Nüsse, J. Klingauf and A. Studer, Org. Lett., 2018, 20, 752-755.

54 A. Khazaei, M. Khazaei and M. Nasrollahzadeh, Tetrahedron, 2017, 73, 5624-5633.

55 H. A. Patel, L. A. Patel and A. V. Bedekar, New J. Chem., 2016, 40, 8935-8945.

56 M. Nasrollahzadeh and S. M. Sajadi, J. Colloid Interface Sci., 2016, 465, 121-127.

57 H. Liu, P. Wang, H. Yang, J. Niu and J. Ma, New J. Chem., 2015, 39, 4343-4350.

58 M. R. Kuram, M. Bhanuchandra and A. K. Sahoo, Angew. Chem., Int. Ed., 2013, 125, 4705-4710.

59 C. E. Castro, E. J. Gaughan and D. C. Owsley, J. Org. Chem., 1966, 31, 4071-4078.

60 A. Arcadi, F. Marinelli and S. Cacchi, Synthesis, 1986, 9, 749751.

61 R. C. Larock, E. K. Yum, M. J. Doty and K. K. C. Sham, J. Org. Chem., 1995, 60, 3270-3271.

62 R. Sanz, M. P. Castroviejo, Y. Fernandez and F. J. Fananas, J. Org. Chem., 2005, 70, 6548-6551.

63 G. S. Gill, D. W. Grobelny, J. H. Chaplin and B. L. Flynn, J. Org. Chem., 2008, 73, 1131-1134. 
64 N. akai, N. Uchida and T. Konakahara, Tetrahedron Lett., 2008, 49, 3437-3440.

65 J. R. Wang and K. Manabe, J. Org. Chem., 2010, 75, 53405342.

66 R. Wang, S. Mo, Y. Lu and Z. Shen, Adv. Synth. Catal., 2011, 353, 713-718.

67 Z. Zhou, G. Liu, Y. Shen and X. Lu, Org. Chem. Front., 2014, 1, 1161-1165.

68 C. H. Yeh, W. C. Chen, P. Gandeepan, Y. C. Hong, C. H. Shih and C. H. Cheng, Org. Biomol. Chem., 2014, 12, 9105-9108.

69 D. H. Lee, K. H. Kwon and C. S. Yi, J. Am. Chem. Soc., 2012, 134, 7325-7328.

70 V. S. Thirunavukkarasu, M. Donati and L. Ackermann, Org. Lett., 2012, 14, 3416-3419.

71 S. Mochida, M. Shimizu, K. Hirano, T. Satoh and M. Miura, Chem.-Asian J., 2010, 5, 847-851.
72 K. Tsuchikama, Y. K. Hashimoto, K. Endo and T. Shibata, Adv. Synth. Catal., 2009, 351, 2850-2854.

73 J. Liao, P. Guo and Q. Chen, Catal. Commun., 2016, 77, 22-25.

74 J. Bonnamour, M. Piedrafita and C. Bolm, Adv. Synth. Catal., 2010, 352, 1577-1581.

75 R. Zhu, J. Wei and Z. Shi, Chem. Sci., 2013, 4, 3706-3711.

76 W. Zeng, W. Wu, H. Jiang, L. Huang, Y. Sun, Z. Chen and X. Li, Chem. Commun., 2013, 49, 6611-6613.

77 M. W. Khan, M. J. Alam, M. A. Rashid and R. Chowdhury, Bioorg. Med. Chem., 2005, 13, 4796-4805.

78 A. Gómez-Suárez, Y. Oonishi, A. R. Martin and S. P. Nolan, Beilstein J. Org. Chem., 2016, 12, 172-178.

79 A. Gopi Krishna Reddy, J. Krishna and G. Satyanarayana, Tetrahedron Lett., 2012, 53, 5635-5640. 